\title{
Sunflower Methyl Ester as an Engine Fuel: Performance Evaluation and Emissions Analysis
}

\author{
Bjorn S. Santos, Sergio C. Capareda, and Jewel A. Capunitan \\ Department of Biological and Agricultural Engineering, Texas A\&M University, College Station, TX 77843, USA \\ Correspondence should be addressed to Bjorn S. Santos; santos_bjorn@tamu.edu
}

Received 5 September 2013; Accepted 26 September 2013

Academic Editors: K. T. Lee and Y.-C. Lin

Copyright ( 2013 Bjorn S. Santos et al. This is an open access article distributed under the Creative Commons Attribution License, which permits unrestricted use, distribution, and reproduction in any medium, provided the original work is properly cited.

\begin{abstract}
Biodiesel from sunflower oil offers a potential as an alternative to petroleum-based diesel fuel and must be evaluated in terms of the resulting engine performance and exhaust emissions. Two diesel engines rated at $14.2 \mathrm{~kW}$ (small) and $60 \mathrm{~kW}$ (large) were operated on pure sunflower methyl ester (SFME) and its blends with a reference diesel (REFDIESEL). Results showed that less power and torque were delivered by both the small and large engines when ran on pure SFME than on REFDIESEL, while brakespecific fuel consumption (BSFC) was found to be higher in pure SFME. Blends of SFME with REFDIESEL (B5 and B20) showed negligible power loss and similar BSFC with the REFDIESEL. Higher concentrations of nitrogen oxides $\left(\mathrm{NO}_{x}\right)$, carbon dioxide $\left(\mathrm{CO}_{2}\right)$, and total hydrocarbons (THC) in the exhaust emissions were observed for both pure SFME and SFME-REFDIESEL fuel blends. Comparison with soybean methyl ester indicates similar engine performance. Thus, blends of SFME with diesel may be used as a supplemental fuel for steady-state nonroad diesel engines to take advantage of the lubricity of biodiesel as well as contributing to the goal of lowering the dependence to petroleum diesel.
\end{abstract}

\section{Introduction}

Biodiesel is an alternative fuel deemed to augment, if not to replace, petroleum diesel supply in the current world's energy situation. It is a mixture of monoalkyl esters of long chain fatty acids (FAME) derived from a renewable lipid feedstock, such as vegetable oil or animal fat [1-3]. With growing concern over possible scarcity in petroleum fuel reserves as well as increasing awareness on global environmental issues, the use of biodiesel either solely or blended with petroleum diesel has been investigated and promoted among energy producers and end-users $[1,2,4,5]$.

Biodiesel can be produced from the transesterification of any triglyceride feedstock, which includes oil-bearing crops, animal fats, and algal lipids [6]. These feedstock materials are rather extremely viscous, and converting them into esters achieves the purpose of lowering their viscosity [7]. Various sources have been identified and used as biodiesel feedstock, including edible oils, nonedible oils, wild oils, used cooking oils, and animal fats [5]. Soybean oil has been the major source in the United States, with approximately $244 \mathrm{M}$ lbs consumed in November 2012 [8]. However, soybean oil alone cannot satisfy the necessary feedstock quantity for biodiesel production since it accounts only for $13.5 \%$ of the total production, owing to its use in the food industry as well, and thus, there is a need to look for other feedstock sources [9]. Oil from such feedstock as sunflower has been identified as potential biodiesel source.

Biodiesel production from sunflower oil has been widely investigated in various studies which include optimization of the transesterification process conditions, variation in catalysts, and blending with other oils prior to biodiesel production [10-16]. However, another important aspect in biodiesel research that must be considered is the assessment of its performance as an engine fuel. There has been much of literature that discussed biodiesel performance in an engine specifically the effect of using biodiesel blends on engine power and fuel economy [17]. Biodiesel produced from different oil sources has been employed in a variety of engine configurations. However, variation in the quality of the biodiesel caused by differences in the esterification process and the raw materials used, among others [18], may affect engine performance. 
Aside from engine testing, emissions associated with the use of biodiesel also need to be evaluated to assess its cleanliness as a fuel. The Environmental Protection Agency (EPA) reported that nonroad diesel engines have a substantial role in contributing to the nation's air pollution, and therefore stricter emission standards were imposed with regards to the amounts of particulate matter, nitrogen oxides, and sulfur oxides [19]. This necessitates the analysis of biodiesel emissions to ensure compliance with current EPA regulations.

Thus, the application of biodiesel produced from sunflower oil as an engine fuel is investigated in this study and compared with those of soybean oil biodiesel and a reference petroleum diesel. The main objective is to evaluate the performance of sunflower methyl ester as an engine fuel in terms of engine performance and emission characterization. In particular, this study aims to (a) assess fuel properties of the sunflower methyl ester in accordance with ASTM standards; (b) determine the effect of blending percentage of biodiesel on the characteristic engine performance (i.e., net brake power, torque, and specific consumption); (c) determine the relationship between pollutant concentrations (i.e., $\mathrm{NO}_{x}$, THC, $\mathrm{CO}$, and $\mathrm{CO}_{2}$ ) in a diesel engine exhaust and the percentage of biodiesel in fuel blends; and (d) to compare performance and exhaust emissions when using sunflower oil methyl ester (SFME), soybean oil methyl ester (SME), and a reference diesel (REFDIESEL).

\section{Materials and Methods}

2.1. Materials. Sunflower oil biodiesel (SFME) was prepared from previously extracted and refined oils at the Bio-Energy Testing and Analysis (BETA) Laboratory at Texas A\&M University, College Station, TX. The following conventional biodiesel reaction conditions were used: reaction time, $1 \mathrm{~h}$; weight of catalyst, $0.4 \%$ wt. of initial oil weight; vol. of methanol, $15 \%$ vol. of oil; reaction temperature: $50^{\circ} \mathrm{C}$. The biodiesel obtained was then blended with a reference diesel (REFDIESEL-ULSD standard no. 2 reference fuel). The test fuels were analyzed to determine if they meet ASTM 6751-07 standard. Fuels and fuel blends are as follows:

\section{5\% SFME-95\% REFDIESEL-B5 SFME, 20\% SFME-80\% REFDIESEL-B20 SFME, 100\% SFME-0\% REFDIESEL-B100 SFME.}

Soybean oil biodiesel (SME) and the reference diesel were purchased commercially.

2.2. ASTM Characterization of Biodiesel Fuels. ASTM characterization of the biodiesel was done to ensure that the test fuel used in the study conforms to the ASTM D675108 standard (ASTM, 2008). Some of the referenced procedures in the ASTM 6751 standard were conducted in the BETA lab. Such procedures were cloud and pour point (ASTM D2500), flash point (ASTM D93), water and sediment (ASTM D2709), kinematic viscosity (ASTM D445), acid number (ASTM D664), and gross heating value (ASTM D4809).
TABLE 1: General specifications for Yanmar 3009D and JD4045DF150 diesel engines.

\begin{tabular}{|c|c|c|}
\hline Specification & Yanmar 3009D & JD 4045DF150 \\
\hline Rated power & $\begin{array}{c}14.2 \mathrm{~kW}(19 \mathrm{hp}) \\
\text { at } 3000 \mathrm{rpm}\end{array}$ & $\begin{array}{c}60 \mathrm{~kW}(80 \mathrm{hp}) \text { at } \\
2700 \mathrm{rpm}\end{array}$ \\
\hline $\begin{array}{l}\text { Number of } \\
\text { cylinders }\end{array}$ & 3 & 4 \\
\hline Bore & $72 \mathrm{~mm}$ & $106 \mathrm{~mm}$ \\
\hline Stroke & $72 \mathrm{~mm}$ & $127 \mathrm{~mm}$ \\
\hline Displacement & $0.879 \mathrm{~L}$ & $4.5 \mathrm{~L}$ \\
\hline $\begin{array}{l}\text { Compression } \\
\text { ratio }\end{array}$ & $22.6: 1$ & $17.6: 1$ \\
\hline $\begin{array}{l}\text { Combustion } \\
\text { system }\end{array}$ & $\begin{array}{l}\text { Indirect } \\
\text { injection }\end{array}$ & Direct injection \\
\hline Aspiration & Natural & Natural \\
\hline
\end{tabular}

FIgUre 1: The dynamometer test system showing the (a) $14.2 \mathrm{~kW}$ Yanmar 3009D diesel engine and (b) the dynamometer.

2.3. Engine Performance and Exhaust Emissions Testing. Engine performance and exhaust emissions testing were conducted at the BETA Lab engine testing facility. Instrumentation needed to measure some of the EPA regulated emissions, such as $\mathrm{CO}, \mathrm{CO}_{2}, \mathrm{NO}_{x}, \mathrm{THC}$, and $\mathrm{SO}_{2}$, was in place.

2.3.1. Test Equipment. The BETA lab uses two test engines with their own respective test beds and dynamometer setups. One of the test engines was a 3-cylinder Yanmar 3009D diesel engine rated at $14.2 \mathrm{~kW}$ (Figure 1). Table 1 lists the general specifications of the small and large test engine. The engine load was controlled by a water-cooled eddy current absorption dynamometer with a Dynamatic EC 2000 controller. The maximum braking power of the dynamometer was rated at $22.4 \mathrm{~kW}(30 \mathrm{hp})$ at $6000 \mathrm{rpm}$.

The large test engine used in the study, shown in Figure 2, was an in-line, 4 -cylinder, $4.5 \mathrm{~L}$, four stroke, naturally aspirated John Deere diesel engine. It was connected to a $450 \mathrm{HP}$ water-cooled eddy current inductor dynamometer (Pohl Associates Inc., Hatfield, PA). The engine's rated power was at $80 \mathrm{HP}$ with rated speed of $2500 \mathrm{rpm}$. The engine's 
TABLE 2: Properties of test fuels and the reference diesel according to ASTM standards.

\begin{tabular}{|c|c|c|c|c|c|}
\hline Property & Method & Specifications & Reference diesel & Sunflower ME & Soybean ME \\
\hline Flash point, ${ }^{\circ} \mathrm{C}$ & D93 & $130 \mathrm{~min}$. & 128 & 192 & 199 \\
\hline Water and sediment, \%vol & D2709 & 0.050 max. & $<0.01$ & $<0.01$ & $<0.01$ \\
\hline Kinematic viscosity, $40^{\circ} \mathrm{C}, \mathrm{mm}^{2} / \mathrm{s}$ & D445 & $1.9-6.0$ & 2.3 & 6.3 & 4.7 \\
\hline Sulfur, ppm & D5453 & 15 max. & Unknown & Unknown & 4 \\
\hline Cetane number & D613 & $47 \mathrm{~min}$. & Unknown & Unknown & 55 \\
\hline Cloud point, ${ }^{\circ} \mathrm{C}$ & D2500 & Report & -35 & 2 & -6 \\
\hline Carbon residue, \%mass & $\mathrm{D} 4530$ & 0.050 max. & Unknown & Unknown & 0.01 \\
\hline Acid number, mg KOH/g sample & D664 & $0.50 \max$ & 0.04 & Unknown & 0.19 \\
\hline Distillation temperature, ${ }^{\circ} \mathrm{C}$ & D1160 & 360 max. & Unknown & Unknown & 329 \\
\hline Oxidation stability, hours & EN14112 & $3 \mathrm{~min}$. & Unknown & Unknown & 7.2 \\
\hline Gross heating value, $\mathrm{MJ} / \mathrm{kg}$ & D4809 & Report & 42.7 & 38.2 & 38.8 \\
\hline
\end{tabular}

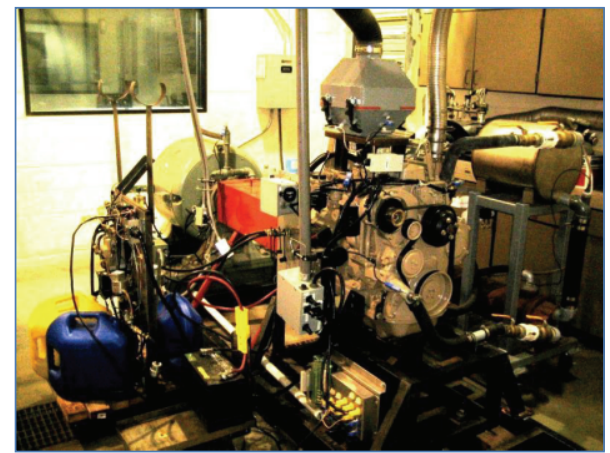

FIGURE 2: JD 4045DF150 diesel engine used for performance and emissions testing.

general specifications were listed in Table 2. The engine load and throttle were controlled by a multiloop Inter-Loc $\mathrm{V}$ dynamometer and throttle controller (Dyne Systems Inc., Jackson, WI).

2.3.2. Instrumentation and Data Acquisition Equipment. Figure 3 shows the schematics of the data acquisition system for the Yanmar 3009D and JD 4045DF150 diesel engines. Instrumentation includes measurement of test cell ambient conditions (barometric pressure, temperature, and humidity), engine speed and torque, fuel flow rates, engine manifold pressures and temperatures, and engine exhaust gaseous emissions measurements. Fuel flow was measured with an AW positive displacement gear-type flow meter with $50 \% \pm 1 \%$ duty cycle. Manifold pressure measurements were taken by strain gauge pressure transducers positioned in the exhaust and intake manifolds. Temperature measurements were measured with shielded type-K thermocouples at roughly the same aforementioned locations as pressure. Engine brake torque and speed were acquired from the dynamometer.

National Instruments (NI) data acquisition equipment (DAQ) was installed in different parts of the test engines and the test cell. A fiber optic cable connects the remote computer to the NI PCI-7831R FPGA module. Thermocouples and pressure transducers were connected to the SCXI 1320 and SCXI 1326 signal conditioning units. Torque and engine speed data are collected using a NI Labview program developed for this research. Exhaust emissions such as $\mathrm{CO}, \mathrm{NO}_{x}$, and $\mathrm{SO}_{2}$ were measured with electrochemical SEM sensors, while $\mathrm{CO}_{2}$ and total hydrocarbons (THC) were measured with NDIR sensors, all assembled in an Enerac model 3000E emissions analyzer.

The emissions analyzer has a capability of measuring 0 to 3500 ppm $\mathrm{NO}_{x}$ concentrations; 0 to $2000 \mathrm{ppm} \mathrm{CO}$ and $\mathrm{SO}_{2}$ concentrations, with an accuracy of $\pm 2 \%$ of reading; 0 to $5 \%$ by volume total hydrocarbon concentrations; and 0 to $20 \% \mathrm{CO}_{2}$ concentrations with an accuracy of $\pm 5 \%$ of reading. In addition, it also measures the ambient temperature, stack temperature, stack velocity, and test cell $\mathrm{O}_{2}$ concentrations.

2.3.3. Experimental Method. Engine power tests are conducted in accordance with SAE Standard Engine Power Test Code for diesel engines (SAE J1349 Revised MAR2008). Baseline engine performance and emissions tests are performed using ULSD reference diesel fuel. Engine performance data for ULSD reference diesel were corrected to the standard atmospheric conditions using the compression ignition engine correction formula according to SAE J 1349MARCH2008.

Variables such as air and relative humidity are carefully monitored. Fuel temperature is controlled as outlined in the test procedure. Tests were conducted in a randomized complete block design (RCBD) to prove that the fuel sequence is not significant to the results of the study. Response variables were the following: net brake power $(\mathrm{kW})$, torque $(\mathrm{N}-\mathrm{m})$, fuel consumption $(\mathrm{L} / \mathrm{h}), \mathrm{NO}_{x}$ concentrations (ppm), unburned hydrocarbon concentrations (ppm), CO concentrations (ppm), and $\mathrm{CO}_{2}$ concentrations (\%).

The BETA lab is equipped with a NI Labview program that can perform remote-based switching of fuel source. This provides changing of test fuels without turning off the engine. At each fuel change, the fuel filter was replaced and then the engine was warmed at idle speed on the new fuel for 15 minutes to purge remaining previous test fuel from 


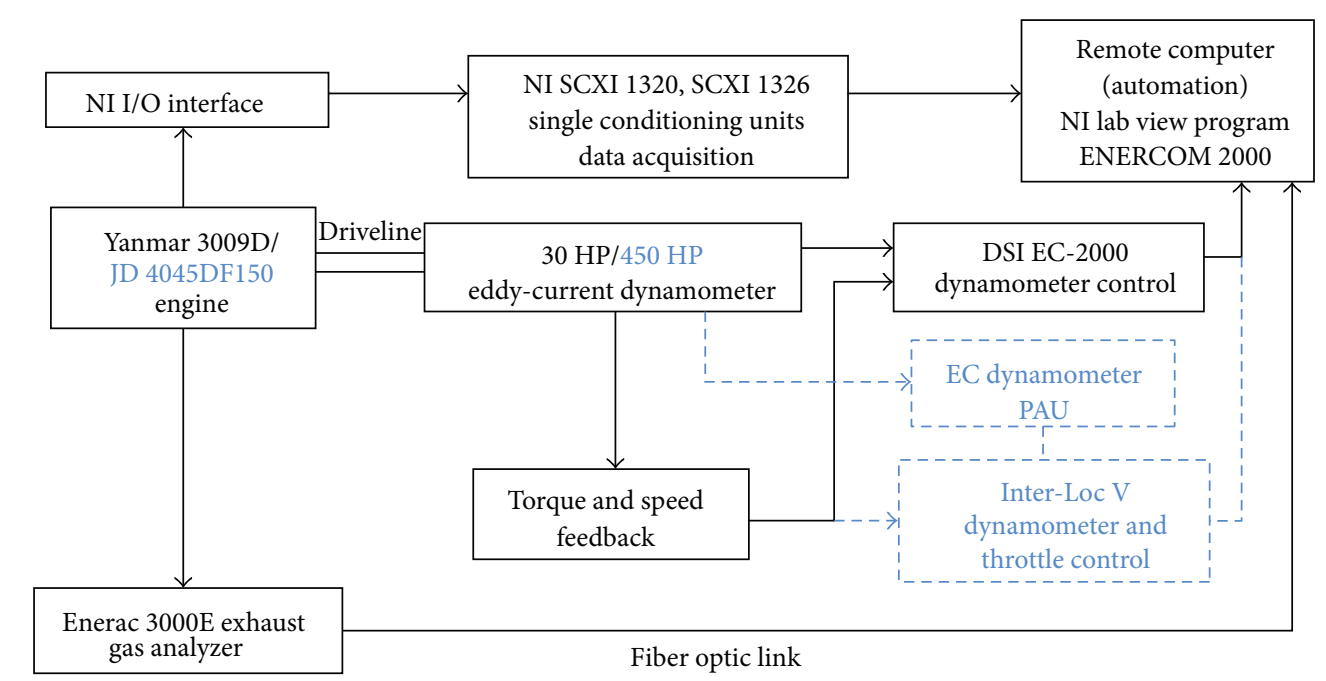

FIGURE 3: Schematics of the data acquisition system for the Yanmar 3009D and JD 4045DF150 diesel engines.

the engine's fuel system. Then, the engine was operated at full throttle and prepared for the next performance testing. Also, a new set of sintered filters for the exhaust emissions analyzer was installed prior to the next emissions testing.

The important sources of uncertainty in this study are (1) supply of consistent quality of fuel, (2) proper control over relevant engine parameters (e.g., speed and load), and (3) proper use and calibration of the measurement instruments. To minimize the first source of uncertainty, test fuels were processed in such a way that it will match up ASTM 6751 standard. Fresh batch of biodiesel was used to ensure consistency of the fuel quality in the experiment. The uncertainty associated with the second source was minimized by depending on the proper control and the use of engine instrumentation and controller equipment. Parameters, such as engine speed, fuel flow rate, and load accuracy, were matched to within $\pm 5 \mathrm{RPM}, \pm 1 \%$ of the reading, and $\pm 0.05 \%$ of the rated output, respectively. Finally, the uncertainty associated with the third source was minimized by calibrating emissions equipment, each day prior to start of testing, and all other instruments (pressure transducers, thermocouples, flow rate meters, etc.) on routine basis.

In order to understand the effect of the biodiesel on engine combustion efficiency, the brake specific fuel consumptions (BSFC) for the test fuels and each fuel blend were measured at peak torque condition. This condition was chosen since it is the point of minimum air/fuel ratio and maximum smoke [20]. Results were compared to those of the control fuel using statistical analysis procedures (ANOVA and LSD).

\section{Results and Discussion}

3.1. Characteristics of Test Fuels. Table 2 shows the characteristics of the test fuels SFME, SME, and REFDIESEL as determined following ASTM standards. Both biodiesels have higher flash point than the reference diesel, an indication of good fuel quality in terms of safety during transport, handling, and storage [2]. Water and sediment are below the maximum limit as well as the kinematic viscosity except for the sunflower biodiesel. The gross heating values are lower for both biodiesels than that for the reference diesel. These differences in fuel properties can lead to differences in engine performance, as will be discussed in the succeeding paragraphs.

3.2. Engine Performance. The performances of the engines at full load (the fuel pump is at the maximum delivery setting) using test fuels (SFME, SME, and PME-REFDIESEL blends) were determined in accordance to SAE J1349 Power test code procedures. Baseline engine performance and emissions tests were performed using standard no. 2 ULSD fuel (REFDIESEL). Corrected values of the net brake power and brake-specific fuel consumption for ULSD, as described earlier, were also presented in the following sections.

\subsubsection{Net Brake Power}

Small Engine. The net brake power at different engine speeds and fuel blends is presented in Figure 4. For the plot at different engine speeds, there is an initial gradually increasing trend in power until a maximum is reached and falls rapidly as the engine speed is further increased. Power decreases after a maximum is reached due to the increase in friction at higher speeds.

Comparison with different fuel blends shows that the net brake power decreased with an increase in the percentage of SFME in the blend. However, statistical analysis showed no significant differences among the REFDIESEL, B5 and B20, fuel blends. The corrected net brake power of REFDIESEL was at $13.95 \mathrm{~kW}$, which is $4.5 \%$ higher than the peak net brake power for B100 SFME with $13.3 \mathrm{~kW}$. A study by Kaplan et al. in 2006 [21] on the engine performance of SFME showed a decrease in engine power as well, approximately 5-10\% lower than that for a regular diesel. Some studies, however, showed a slight increase in power, as was found out by Usta et al. 


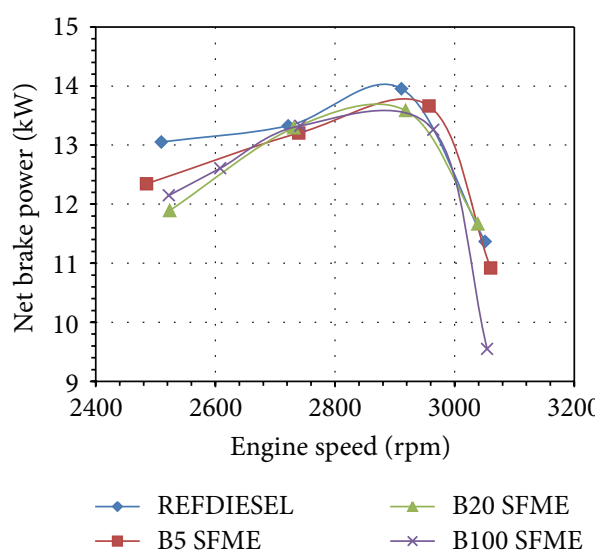

(a)

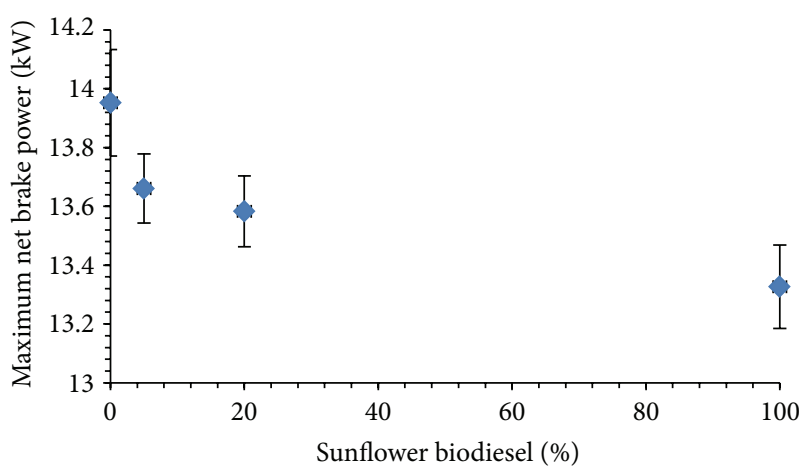

(b)

FIGURE 4: Net brake power of the Yanmar engine at various SFME-REFDIESEL fuel blends and engine speeds.

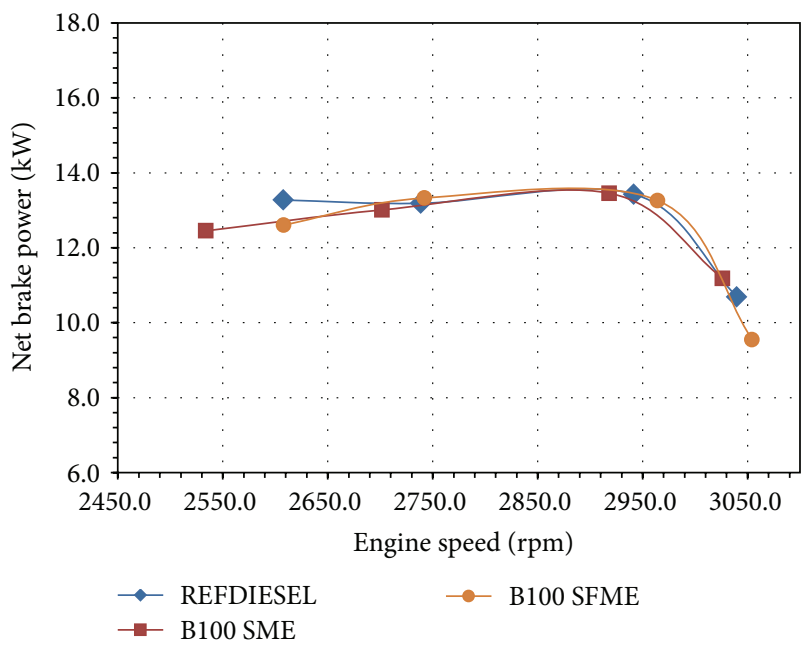

Figure 5: Net brake power of the Yanmar engine using SFME, SME and REFDIESEL at varying engine speeds.

[22], where the power slightly increased for the 5\% SFMEdiesel blend but decreased by about $2-3 \%$ for the $30 \%$ blend. Also, Moreno et al. [18] showed no noticeable power loss when using 25, 50, and 75\% blends of SFME and diesel. Three percent (3\%) gain was observed for the $25 \%$ blend, while $1.5 \%$ loss was observed for pure SFME.

The performance of SFME was also compared to that of soybean biodiesel (SME), and the net brake power at different engine speeds is shown in Figure 5. SME followed a similar trend in net brake power at increasing engine speed. It also had similar value of net brake power with REFDIESEL and thus, slightly higher than SFME.

Many studies agree that the use of biodiesel will lead to the reduced engine power and that using fuel blends with small percentages of biodiesel will result in unnoticeable power loss. The decrease in engine power can be attributed to the lower heating value of SFME as compared to the reference

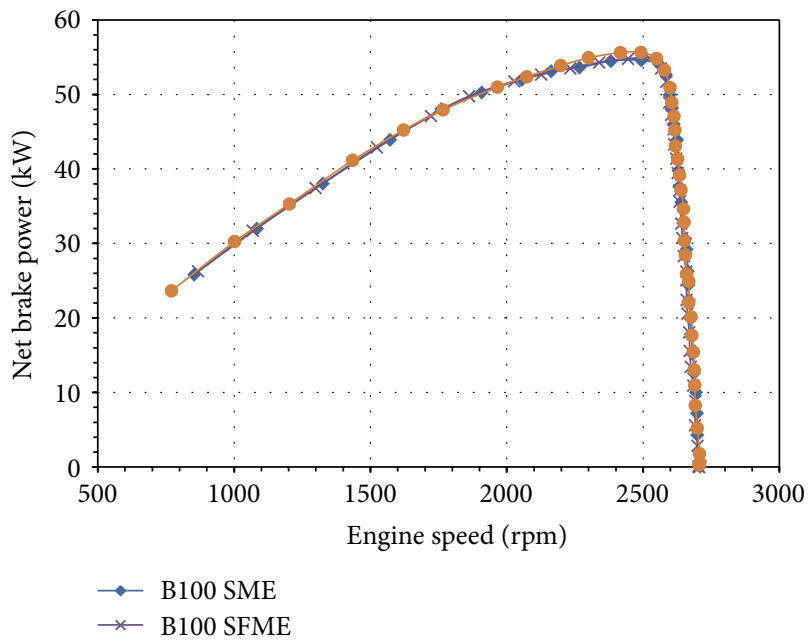

FIGURE 6: Net brake power of the John Deere engine using SFME, SME, and REFDIESEL at varying engine speeds.

diesel. High viscosity of the biodiesel can also have certain effects on the engine power [17].

Large Engine. For the 4-cylinder-80-hp John Deere engine, the net brake power at different engine speeds for the SFME, SME, and reference diesel is also determined as shown in Figure 6. The corrected peak net brake power using REFDIESEL was observed to be the highest compared to the biodiesel fuels. Percent differences in peak net brake power ranged from $0.2 \%$ to $2 \%$.

\subsubsection{Engine Torque}

Small Engine. The engine torque at varying engine speeds and fuel blends is also obtained and shown in Figure 7. The torque follows a similar trend as engine power, whereby it gradually increases at low speed and decreases rapidly after a maximum value is reached. Torque decreases because the 


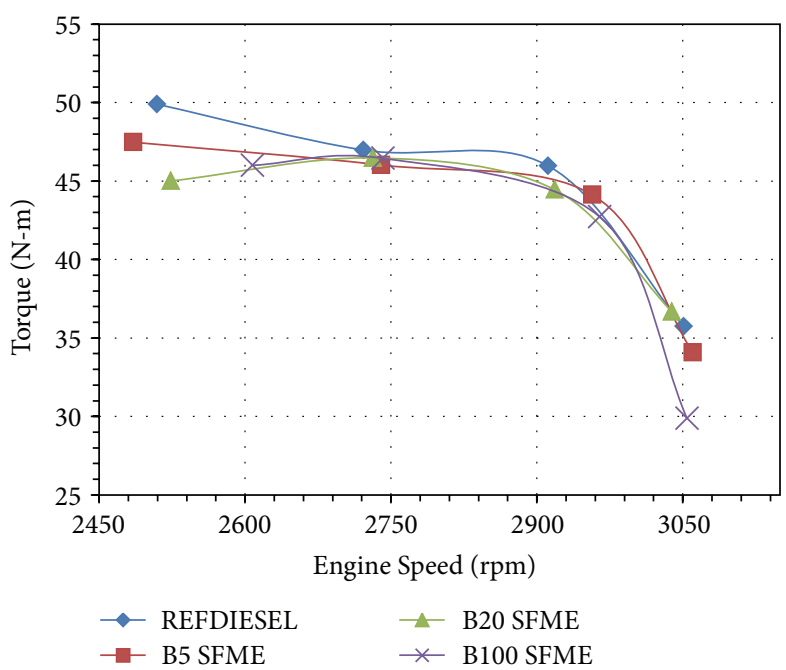

(a)

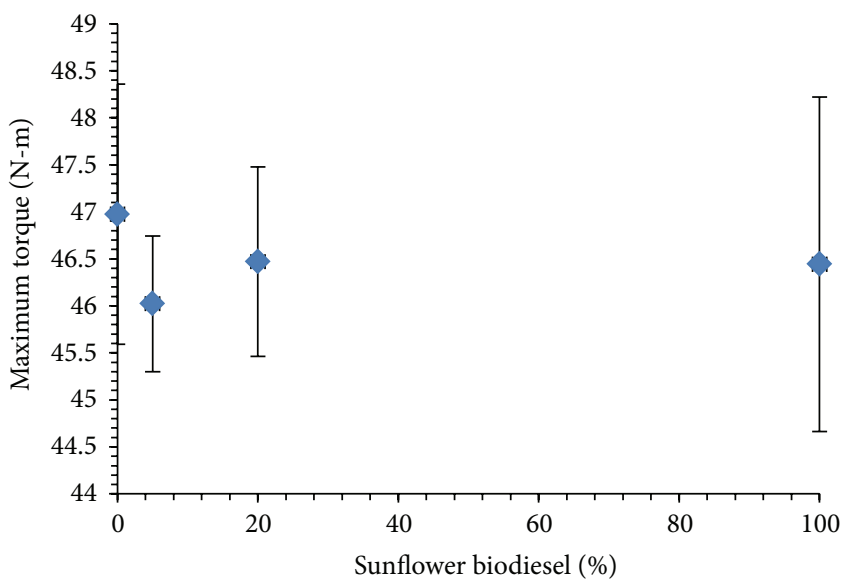

(b)

FIGURE 7: Engine torque of the Yanmar engine at various fuel blends and engine speeds.

engine is unable to ingest a full charge of air at higher speeds [23].

The peak torque values for different SFME blends were lower than the reference diesel by as much as $2 \%$. Among the fuel blends, B20 SFME has the highest peak torque $(46.5 \mathrm{~N}$ $\mathrm{m})$, followed by B100 then B5. The reference diesel has a peak torque of $47.0 \mathrm{~N}-\mathrm{m}$ at a speed of $2700 \mathrm{rpm}$. The slight decrease in torque can as well be attributed to the lower heating value of SFME. Nevertheless, it can be seen from Figure 7 that the maximum torque is maintained for a large range of engine speed, indicating comparative performance of SFME and the reference diesel. Similar observations were reported by Kaplan et al. in their study on the utilization of SFME in a 4-cylinder Peugeot XD3p157 engine [21].

Large Engine. The peak torque values for the large John Deere engine are presented in Figure 8 and indicate higher values for REFDIESEL $(293.2 \mathrm{~N}-\mathrm{m}$ at $770.3 \mathrm{rpm})$ than those for SFME $(289.1 \mathrm{~N}-\mathrm{m}$ at $868.2 \mathrm{rpm})$ and SME $(288.7 \mathrm{~N}-\mathrm{m}$ at $854 \mathrm{rpm}$ ). A similar decrease in peak torque values was observed just as seen in the small engine performance study.

\subsubsection{Brake Specific Fuel Consumption (BSFC)}

Small Engine. The brake specific fuel consumption (BSFC) is a measure of fuel efficiency within the crankshaft of an internal combustion engine and can be obtained by dividing the rate of fuel consumption of the engine by the net brake power [23]. Figure 9 shows the BSFC in relation to varying engine speeds and fuel blends. The BSFC is shown to decrease with an increase in engine speed until it reaches a minimum value and further increases at higher speeds. Greater friction losses at higher speeds contribute to the increase in fuel consumption, while at low speed, the longer time per cycle results in higher heat loss, allowing for more fuel consumption.

At peak torque conditions, the BSFC was found to increase when using pure SFME but has no significant

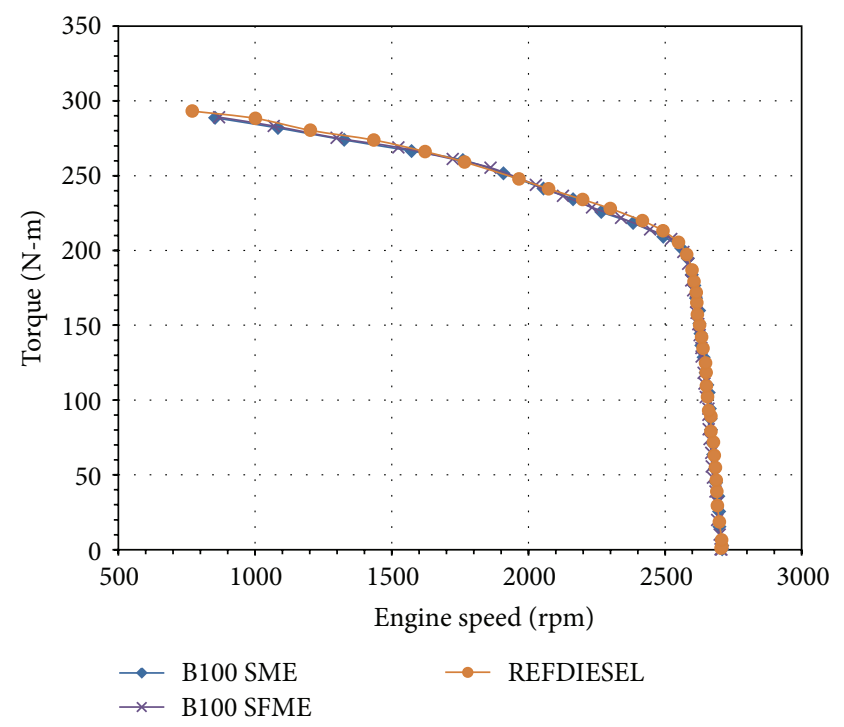

FIGURE 8: Engine torque of the John Deere engine using SFME, SME, and REFDIESEL at varying engine speeds.

difference among the REFDIESEL, B5 and B20, fuel blends. An increase in BSFC was also observed by Moreno et al. [18], when they fueled a four-cylinder, turbocharged, indirect injected Isuzu engine with $100 \%$ SFME. The BSFC increased at approximately $12 \%$ higher than with pure diesel fuel. Kaplan et al. also observed similar results [21]. Fuel consumption increases when using biodiesel due to its low heating value, as well as high density and viscosity as compared to a regular diesel [17].

The BSFC for SFME was also compared with those for SME and REFDIESEL as shown in Figure 10. At peak torque conditions, both SFME and SME obtained higher BSFC compared to the reference fuel. SME's BSFC is around $14 \%$ higher, while SFME's is $5 \%$ higher than that for the 


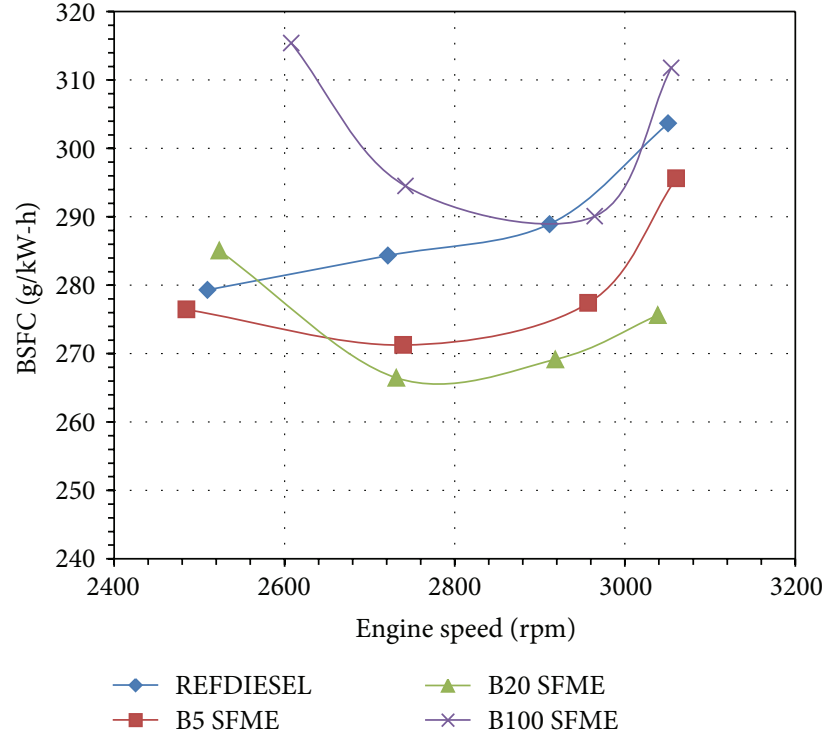

(a)

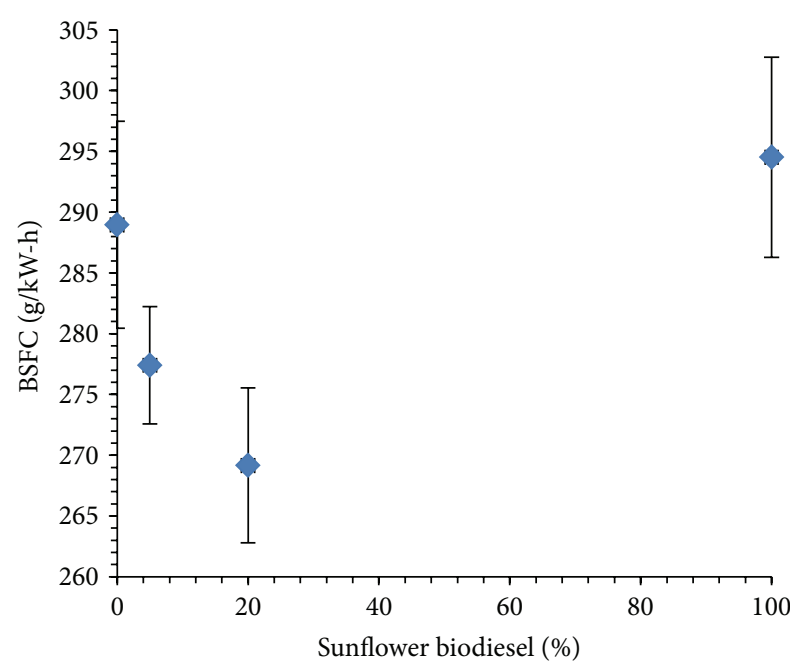

(b)

FIGURE 9: Brake specific fuel consumption (BSFC) of the Yanmar engine at various fuel blends and engine speeds.

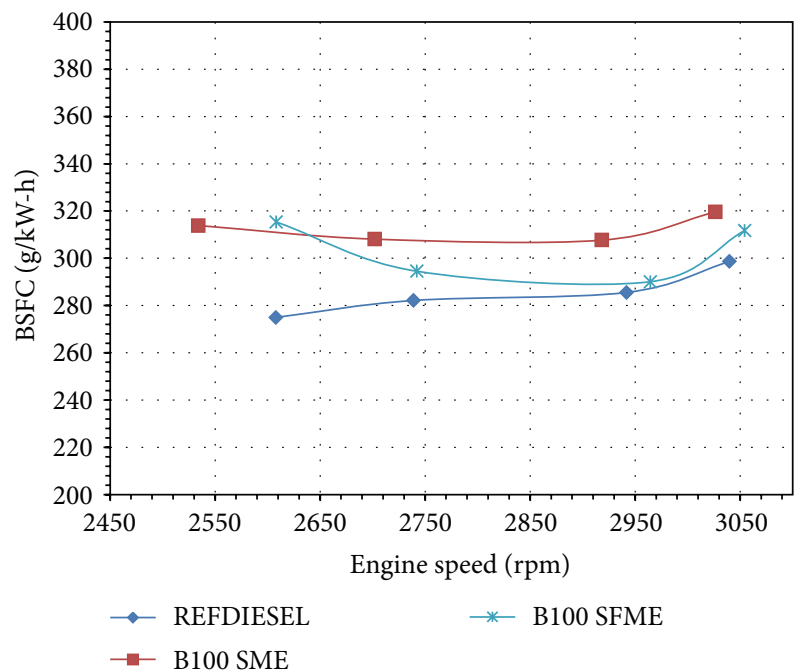

FIGURE 10: BSFC of the Yanmar engine using SFME, SME, and REFDIESEL at varying engine speeds.

REFDIESEL. The two biodiesel fuels were shown to have similar BSFC values by statistical analysis; thus the type of feedstock is not a significant factor affecting BSFC in this study.

Large Engine. The trends in BSFC when running the large John Deere engine with SFME, SME, and REFDIESEL are shown in Figure 11. Results showed that at peak torque conditions, REFDIESEL had the lowest BSFC at $248.78 \mathrm{~g} / \mathrm{kW}$ $\mathrm{h}$, while statistical analysis showed that there is no strong evidence of difference between the BSFC of SME and SFME. A $17.2 \%$ increase in BSFC was observed from SME compared

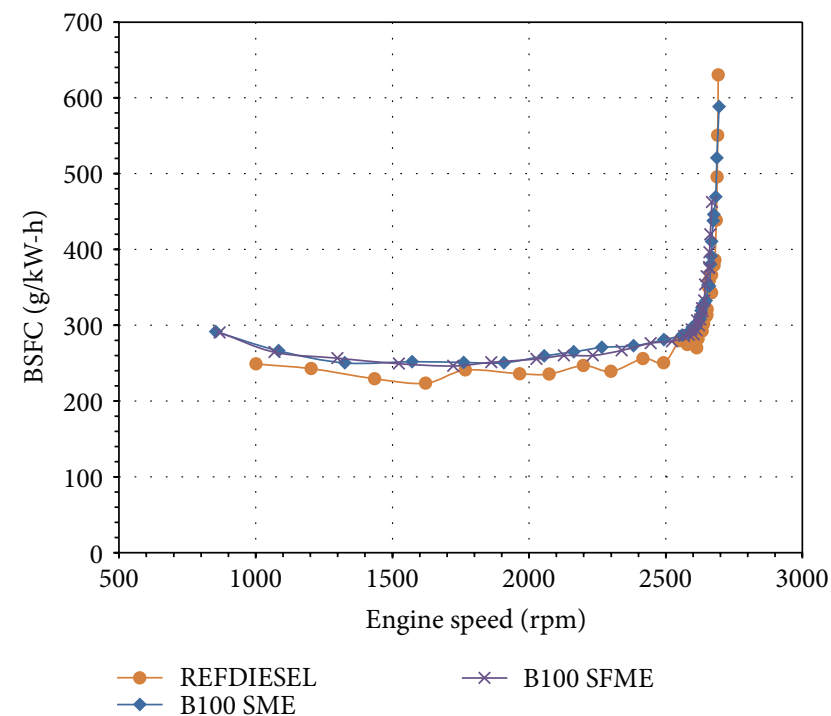

FIgURE 11: BSFC of the John Deere engine using SFME, SME, and REFDIESEL at varying engine speeds.

to REFDIESEL. Similar explanation as with the small engine can be applied in these observations.

3.2.4. Engine Performance Summary. To summarize, SFME delivered less power and torque in reference to pure diesel fuel when used in both small and large engines. They were also found to decrease with increasing percentage of SFME in the fuel blends. The use of SME resulted in more power as compared with SFME. Power is a function of the engine geometry, speed, air/fuel ratio, efficiencies, and fuel properties. Assuming that mechanical losses are similar and 


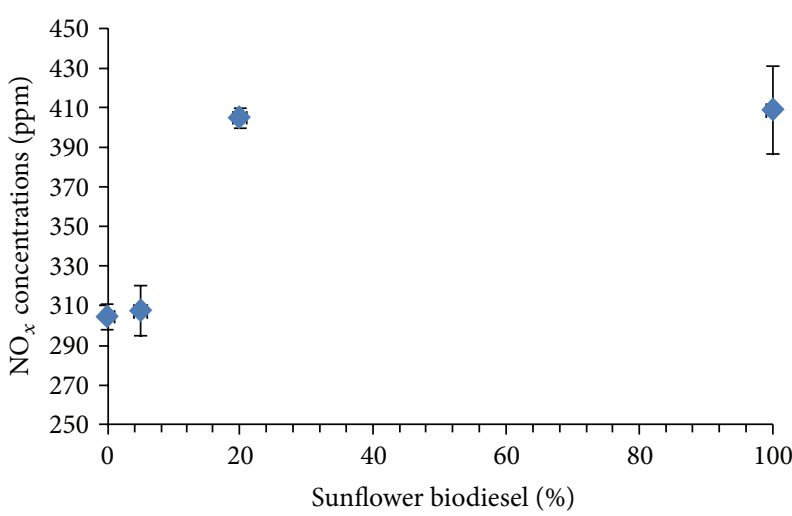

(a)

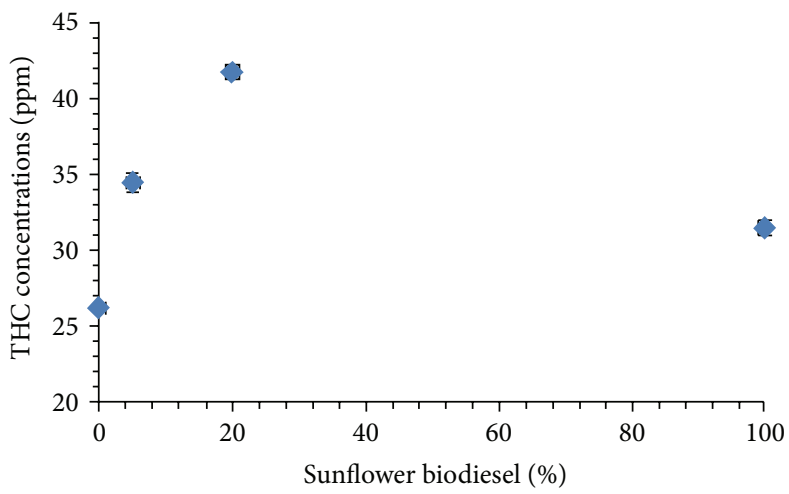

(c)

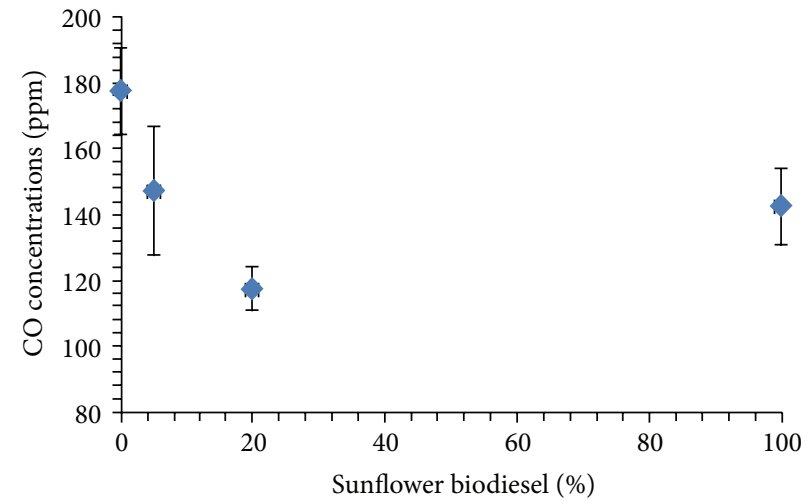

(b)

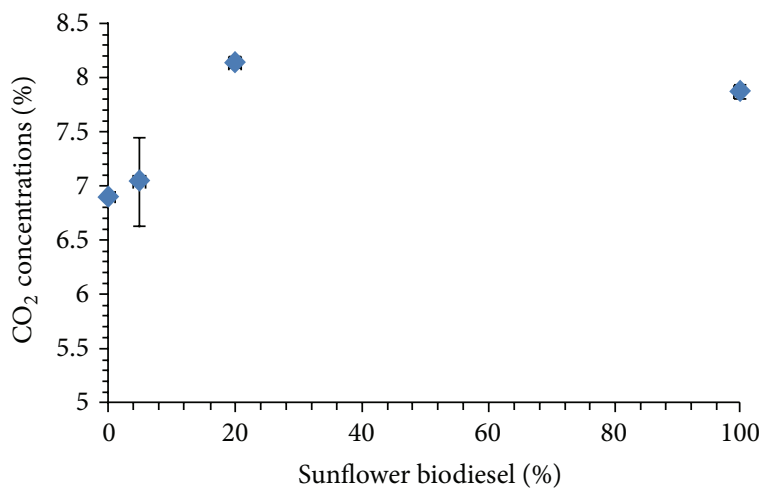

(d)

FIGURE 12: Various exhaust emission concentrations at different SFME fuel blends for the Yanmar diesel engine.

since there were no modifications made in the injection rates or duration for an individual test fuel, power loss may be attributed to the variation in the fuel properties such as heating values and densities between fuels.

Moreover, the rise in mass flow for all biodiesel fuels as observed from both engines can be attributed to the differences in the heating values of the test fuels. The biodiesel fuels have approximately $10 \%$ lower heating values than the reference diesel. The heating value affects the torque being produced, and in order to match that torque with REFDIESEL, pure biodiesel and its blends with REFDIESEL will have to put more energy in the engine, resulting in higher fuel consumption. Also, as far as engine performance is concerned, it was determined based on the statistical analyses performed on BSFC at peak torque conditions for both engines that the BSFC of $100 \%$ SME and SFME were statistically the same. The BSFC of both fuels, however, are higher (5-14\%) than the REFDIESEL.

3.3. Exhaust Emissions. Since the composition of the fuel affects the emissions of an engine, emissions from biodiesel fuel are also different as compared to those of petroleum diesel. Due to its higher oxygen content ( 10-12 wt.\%), biodiesel has less heating value and yields less particle emissions. Additional advantage is the absence of sulfur in biodiesel, thus removing the typical aerosols derived from sulfuric acid formed during diesel fuel combustion. However, it should be noted that the results can also be affected by the type of engine and its condition [24].

Some of the EPA regulated emissions determined in this research were $\mathrm{CO}, \mathrm{CO}_{2}, \mathrm{NO}_{x}, \mathrm{SO}_{2}$, and total hydrocarbons. The Enerac 3000E exhaust emissions analyzer was used for the emissions testing. Data presented in this section are the average of three readings for SME, PME, and RME and their blends with REFDIESEL and a single reading for SFME and its blends with REFDIESEL fuel.

3.3.1. Small Engine Emissions. The trends observed concerning $\mathrm{NO}_{x}$ emissions while testing the Yanmar engine clearly indicated that as the level of SFME in the blend increased, $\mathrm{NO}_{x}$ emissions levels emitted by the engine also increased (Figure 12). The largest increase in $\mathrm{NO}_{x}$ emissions can be seen when using pure SFME, which is about $34 \%$ higher than that of REFDIESEL. The $\mathrm{NO}_{x}$ emissions when using pure SFME in an automobile engine were also found by Muñoz et al. [24] to be always larger than those with diesel fuel, but results were not consistent with the SFME-diesel blends. A study by Moreno et al. [18] also reported that the $\mathrm{NO}_{x}$ emission of a four-cylinder, turbocharged, indirect-injected Isuzu engine using pure SFME was only $5 \%$ higher than that of diesel fuel. The increase in $\mathrm{NO}_{x}$ emissions could have been affected by the differences in the fuel properties between diesel and biodiesel. According to Moser et al. [25], the higher density and viscosity of the biodiesel imply that 


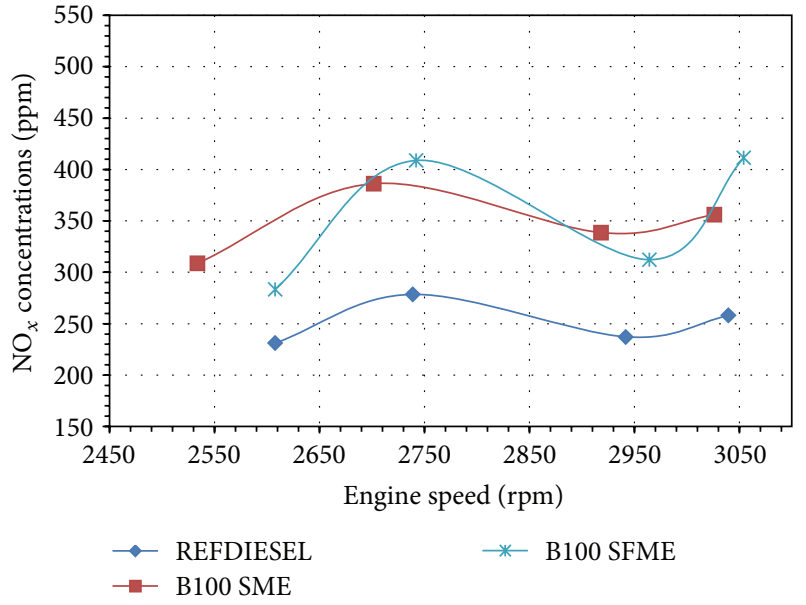

(a)

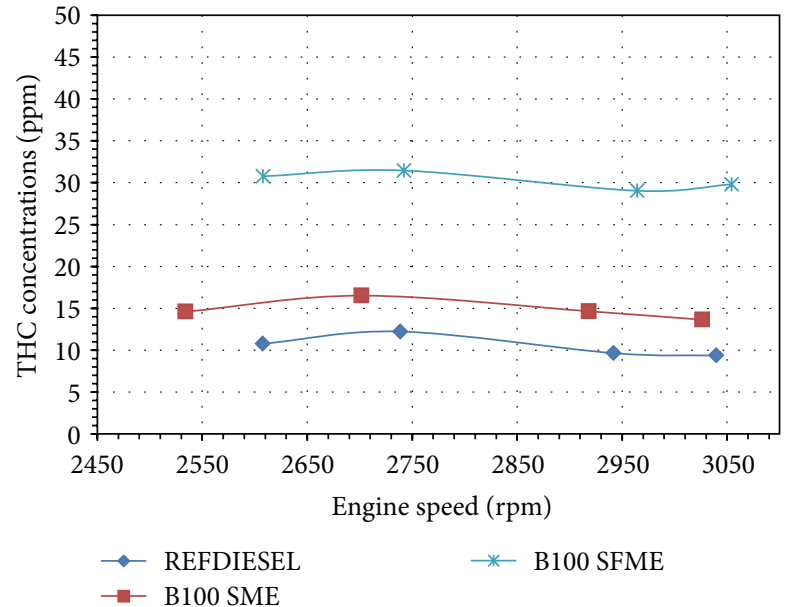

(c)

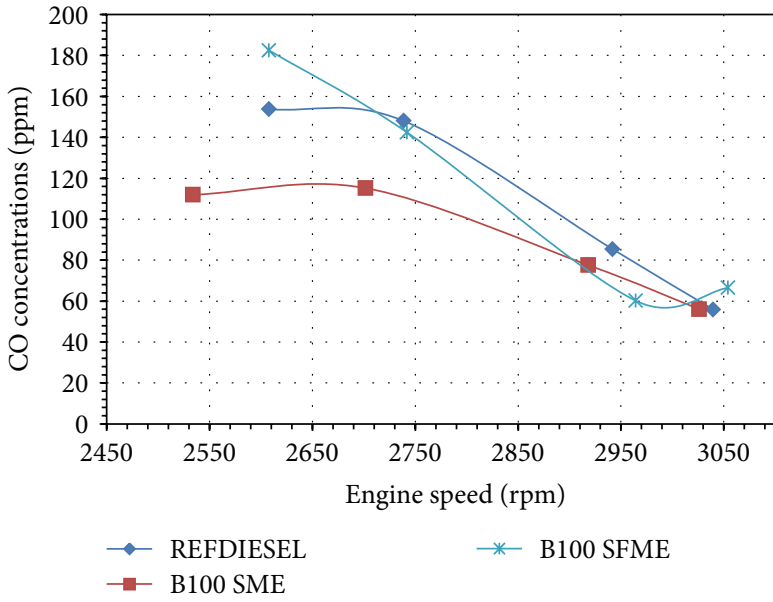

(b)

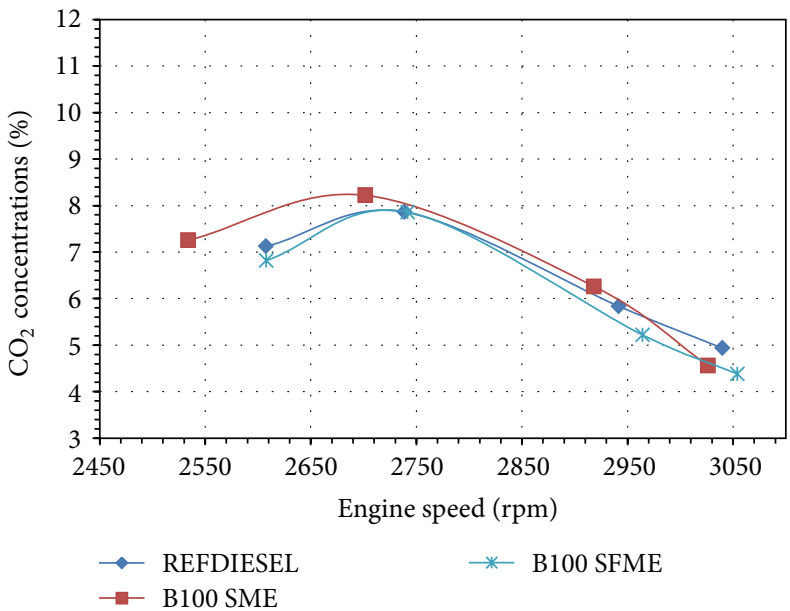

(d)

FIGURE 13: Various emission concentrations of the Yanmar engine using SFME, SME, and REFDIESEL at varying engine speeds.

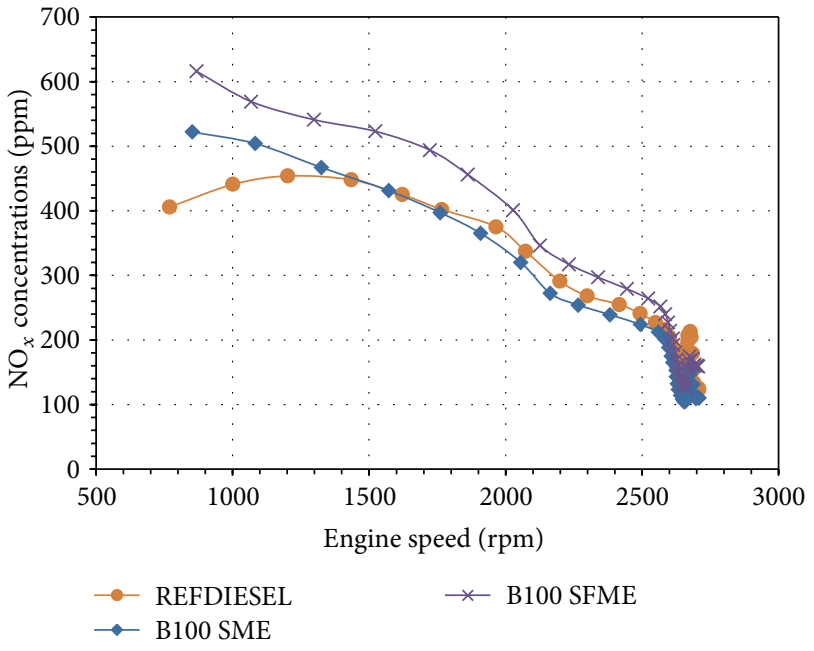

FIGURE 14: $\mathrm{NO}_{x}$ emissions of the John Deere engine using SFME, SME, and REFDIESEL at varying engine speeds. the differential pressure at the advance piston contained in the distributor pump is slightly increased, which in turn advances injection. Also, the amount of fuel injected per cycle could also be affected by variations in density in the fuel. In addition, the fuel spray properties might also be modified due to the increases in the size of the droplets of the fuel, thus affecting burning of the fuel [24]. The increase in $\mathrm{NO}_{x}$ emissions could also be related to the higher oxygen content of biodiesel, as it may provide additional oxygen for $\mathrm{NO}_{x}$ formation [20].

Figure 12 also shows carbon dioxide emissions, which had their peak at B20 SFME and gradually decreased as the percentage of SFME in the blend increased. The $\mathrm{CO}_{2}$ emission for pure SFME was $14 \%$ higher than that for pure diesel. A similar trend was observed for THC concentration, whereby it peaks at B20 SFME and then gradually decreased as it reached B100 SFME. The increase in THC concentrations from REFDIESEL to $100 \%$ SFME was approximately $32 \%$. A similar increase in hydrocarbon emissions was observed 


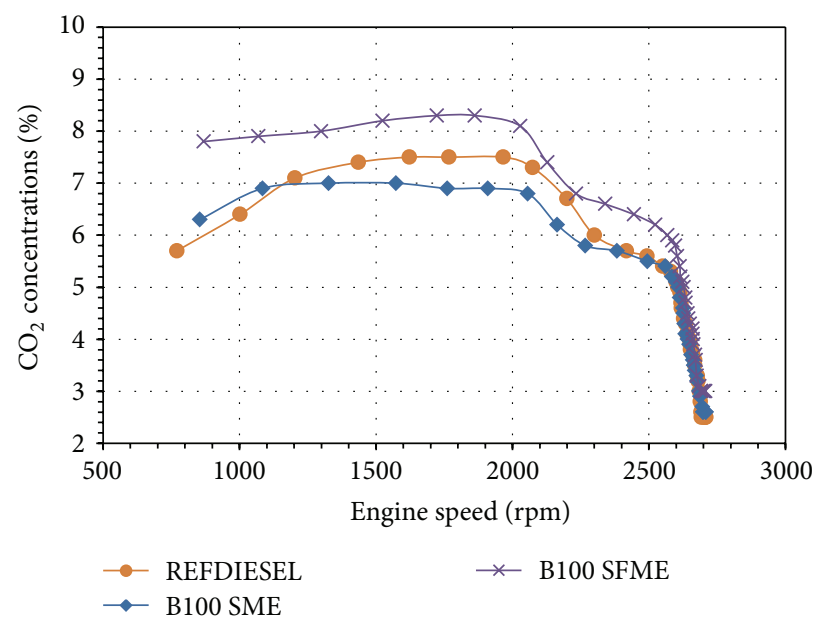

(a)

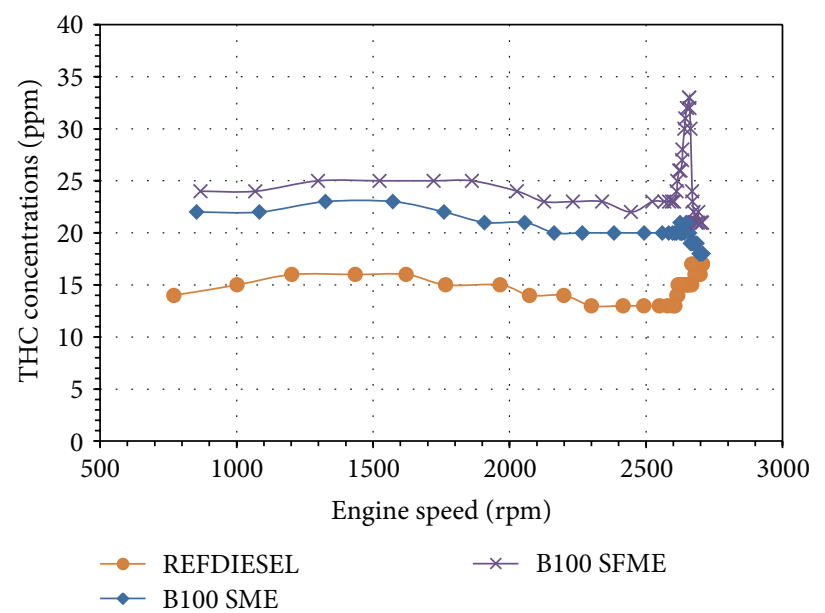

(c)

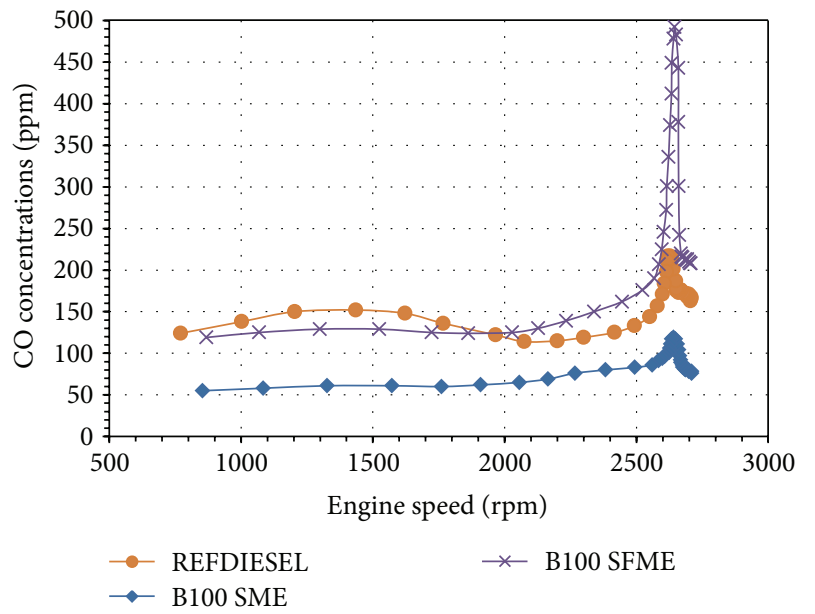

(b)

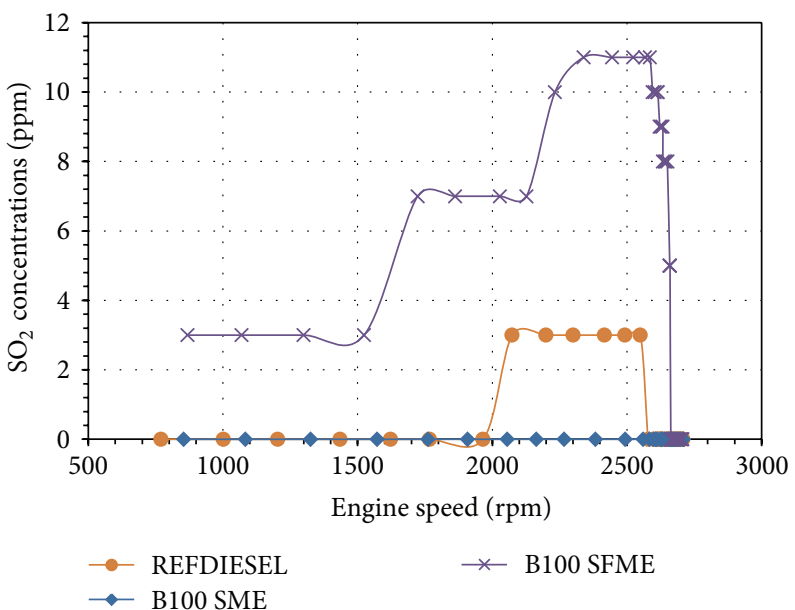

(d)

FIGURE 15: Various exhaust emissions of the John Deere engine using SFME, SME, and REFDIESEL at varying engine speeds.

by Muñoz et al. [24] at high engine speed and load. They explained that hydrocarbon emissions increased since the higher density and viscosity of biodiesel has changed the characteristics of the fuel jet (e.g., size of droplets, penentration, etc.) being released by the injector. It also increases the amount of fuel retained in the interior of the injector nozzle and therefore cannot be incorporated in the combustion chamber immediately, causing an increase in the hydrocarbons without burning.

Finally, the emission of carbon monoxide in the outlet gases decreased as the content of SFME was increased. It reached a minimum at 20\% SFME then gradually increased as the percent of SFME reached $100 \%$. The CO emission is much lower when using pure SFME than when using the reference diesel. Several studies also reported lower CO emission for SFME as compared with diesel fuel [26-28].

The emissions of SFME were also compared with those when using SME as shown in Figure 13. Both biodiesel fuels have higher $\mathrm{NO}_{x}$ concentrations than the reference fuel. Carbon dioxide and carbon monoxide concentrations tend to decrease as the engine speed is increased. The reference diesel, as expected, has higher $\mathrm{CO}$ concentrations than the biodiesel fuels. Total hydrocarbon concentrations seemed to be not affected by the engine speed, but they were considerably higher in SFME emissions than in SME emissions.

3.3.2. Large Engine Emissions. The emissions were also determined for the large John-Deere engine. Figure 14 shows the $\mathrm{NO}_{x}$ emissions of the test engine at speeds between $800 \mathrm{rev} / \mathrm{min}$ and $2700 \mathrm{rev} / \mathrm{min}$ using the different biodiesel test fuels. Generally, $\mathrm{NO}_{x}$ emissions tend to decrease as the speed of the engine is increased. REFDIESEL obtained the lowest peak $\mathrm{NO}_{x}$ concentrations with $454 \mathrm{ppm}$ at $1203 \mathrm{rev} / \mathrm{min}$.

Carbon monoxide, carbon dioxide, and total hydrocarbon concentrations for biodiesel fuels were relatively higher than those for REFDIESEL (Figure 15). $\mathrm{CO}_{2}$ concentrations tend to gradually increase as the speed increases, however, up to a certain point $(2050 \mathrm{rev} / \mathrm{min})$. Afterwards, $\mathrm{CO}_{2}$ concentrations tend to decrease rapidly up to peak power conditions. 
$\mathrm{CO}_{2}$ emissions were higher for SFME as compared with those of SME and REFDIESEL. SME has slightly lower concentrations that the REFDIESEL. Finally, CO and THC concentrations tend to peak as peak power conditions are approached.

3.3.3. Exhaust Emissions Summary. $\mathrm{NO}_{x}$ emissions were found to be always higher when using pure biodiesel (SFME and SME) than with the reference diesel for both small and large engines. Emissions increase with the increase in the percentage of SFME in the fuel blends. $\mathrm{CO}_{2}$ concentrations were observed to be also higher in both small and large engines emissions when using pure SFME and SME. THC emissions were higher in fuel blends of SFME and REFDIESEL such as B5 and B20, but gradually they decreased as the percentage of biodiesel in a fuel blend was increased to B100. Similarly, higher THC emissions were obtained when using pure SFME rather than pure SME. Finally, CO emissions were found to decrease as the percentage of SFME increased and were lower than the REFDIESEL. Differences in exhaust emission concentrations in SFME and SFME-REFDIESEL blends were observed due to changes in properties such as density, viscosity, and heating values, as well as the composition of the fuel. These altogether affect the fuel injection characteristics and the mechanism of fuel burning, thus resulting in variation in emission concentrations of the EPA regulated pollutants.

\section{Conclusions}

The engine performance and exhaust emissions were evaluated for small and large engines operated on pure SFME and its blends with a reference diesel. SME was also tested for comparison purposes. Results showed that less power and torque were delivered by both the small and large engines when ran on pure SFME and SME, while BSFC was found to be higher as compared to the reference diesel. Blends of SFME with REFDIESEL (B5 and B20) showed negligible power loss and similar BSFC with the REFDIESEL. Meanwhile, analyses of the exhaust emissions of the engines when ran on different fuel blends and on pure SFME and SME showed higher $\mathrm{NO}_{x}, \mathrm{CO}_{2}$, and THC concentrations in both pure SFME and SME as well as in the SFME-REFDIESEL fuel blends but lower $\mathrm{CO}$ emissions. Based on these observations, biodiesel may be used as a supplemental fuel for steady-state nonroad diesel engines. When using small percentage of fuel blends, such as B5 and B20, peak power and BSFC were not significantly different from those of pure diesel fuel. Hence, consumers may elect to use these blends in order to take advantage of the lubricity of biodiesel as well as contributing to the goal of lowering the dependence to petroleum diesel.

\section{Conflict of Interests}

The authors of the paper do not have a direct financial relation with the commercial entities mentioned here that might lead to a conflict of interests for any of the authors.

\section{References}

[1] A. Demirbas, "Progress and recent trends in biodiesel fuels," Energy Conversion and Management, vol. 50, no. 1, pp. 14-34, 2009.

[2] A. E. Atabani, A. S. Silitonga, I. A. Badruddin, T. M. I. Mahlia, H. H. Masjuki, and S. Mekhilef, "A comprehensive review on biodiesel as an alternative energy resource and its characteristics," Renewable and Sustainable Energy Reviews, vol. 16, no. 4, pp. 2070-2093, 2012.

[3] M. Canakci and J. Van Gerpen, "Biodiesel production from oils and fats with high free fatty acids," Transactions of the American Society of Agricultural Engineers, vol. 44, no. 6, pp. 1429-1436, 2001.

[4] V. B. Borugadda and V. V. Goud, "Biodiesel production from renewable feedstocks: status and opportunities," Renewable and Sustainable Energy Reviews, vol. 16, pp. 4763-4784, 2012.

[5] E. M. Shahid and Y. Jamal, "Production of biodiesel: a technical review," Renewable and Sustainable Energy Reviews, vol. 15, no. 9, pp. 4732-4745, 2011.

[6] S. K. Hoekman, A. Broch, C. Robbins, E. Ceniceros, and M. Natarajan, "Review of biodiesel composition, properties, and specifications," Renewable and Sustainable Energy Reviews, vol. 16, no. 1, pp. 143-169, 2012.

[7] A. Demirbas, "Importance of biodiesel as transportation fuel," Energy Policy, vol. 35, no. 9, pp. 4661-4670, 2007.

[8] "US EIA Monthly Biodiesel Report," January 2013, http://www .eia.gov/biofuels/biodiesel/production/biodiesel.pdf.

[9] USDA, "US Bioenergy Statistics," February 2013, http://www .ers.usda.gov/data-products/us-bioenergy-statistics.aspx.

[10] S. Taravus, H. Temur, and A. Yartasi, "Alkali-catalyzed biodiesel production from mixtures of sunflower oil and beef tallow," Energy \& Fuels, vol. 23, no. 8, pp. 4112-4115, 2009.

[11] B. R. Moser, "Influence of blending canola, palm, soybean, and sunflower oil methyl esters on fuel properties of biodiesel," Energy \& Fuels, vol. 22, no. 6, pp. 4301-4306, 2008.

[12] G. Vicente, A. Coteron, M. Martinez, and J. Aracil, "Application of the factorial design of experiments and response surface methodology to optimize biodiesel production," Industrial Crops and Products, vol. 8, no. 1, pp. 29-35, 1998.

[13] G. Antolín, F. V. Tinaut, Y. Briceo, V. Castao, C. Pérez, and A. I. Ramírez, "Optimisation of biodiesel production by sunflower oil transesterification," Bioresource Technology, vol. 83, no. 2, pp. 111-114, 2002.

[14] A. Demirbas, "Biodiesel from sunflower oil in supercritical methanol with calcium oxide," Energy Conversion and Management, vol. 48, no. 3, pp. 937-941, 2007.

[15] K. G. Georgogianni, M. G. Kontominas, P. J. Pomonis, D. Avlonitis, and V. Gergis, "Conventional and in situ transesterification of sunflower seed oil for the production of biodiesel," Fuel Processing Technology, vol. 89, no. 5, pp. 503-509, 2008.

[16] G. Guan, N. Sakurai, and K. Kusakabe, "Synthesis of biodiesel from sunflower oil at room temperature in the presence of various cosolvents," Chemical Engineering Journal, vol. 146, no. 2, pp. 302-306, 2009.

[17] J. Xue, T. E. Grift, and A. C. Hansen, "Effect of biodiesel on engine performances and emissions," Renewable and Sustainable Energy Reviews, vol. 15, no. 2, pp. 1098-1116, 2011.

[18] F. Moreno, M. Munoz, and J. Morea-Roy, "Sunflower methyl ester as a fuel for automobile diesel engines," Transactions of the American Society of Agricultural Engineers, vol. 42, no. 5, pp. 1181-1185, 1999. 
[19] EPA, Control of Emissions of Air Pollution from Nonroad Diesel Engines and Fuel; Final Rule, EPA, Washington, DC, USA, 2004.

[20] M. Canakci and J. H. Van Gerpen, "Comparison of engine performance and emissions for petroleum diesel fuel, yellow grease biodiesel, and soybean oil biodiesel," Transactions of the American Society of Agricultural Engineers, vol. 46, no. 4, pp. 937-944, 2003.

[21] C. Kaplan, R. Arslan, and A. Sürmen, "Performance characteristics of sunflower methyl esters as biodiesel," Energy Sources, Part A, vol. 28, no. 8, pp. 751-755, 2006.

[22] N. Usta, E. Öztürk, Ö. Can et al., "Combustion of bioDiesel fuel produced from hazelnut soapstock/waste sunflower oil mixture in a Diesel engine," Energy Conversion and Management, vol. 46, no. 5, pp. 741-755, 2005.

[23] W. W. Pulkrabek, Engineering Fundamentals of the Internal Combustion Engine, Pearson Prentice-Hall, Upper Saddle River, NJ, 2nd edition, 2004.

[24] M. Muñoz, F. Moreno, and J. Morea, "Emissions of an automobile diesel engine fueled with sunflower methyl ester," Transactions of the American Society of Agricultural Engineers, vol. 47, no. 1, pp. 5-11, 2004.

[25] F. Moser, H. Schlogl, and H. Wiesbauer, "Behaviour of rape seed oil methyl ester fueled tractor engines and field experience," in CEC International Symposium on the Performance Evaluation of Automotive Fuels and Lubricants, CTCM/EFTC, Paris, France, 1989.

[26] F. Neto da Silva, A. S. Prata, and J. R. Teixeira, “Technical feasibility assessment of oleic sunflower methyl ester utilisation in Diesel bus engines," Energy Conversion and Management, vol. 44, no. 18, pp. 2857-2878, 2003.

[27] S. Suryanarayanan, V. M. Janakiraman, G. L. N. Rao, and S. Sampath, "Comparative study of the performance and emission characteristics of biodiesels from different vegetable oils with diesel," SAE Technical Paper, 2008-01-1581.

[28] Z. Dulger and C. Kaplan, "Utilization of sunflower methyl ester as a diesel engine fuel," SAE Technical Paper 2001-01-3633. 


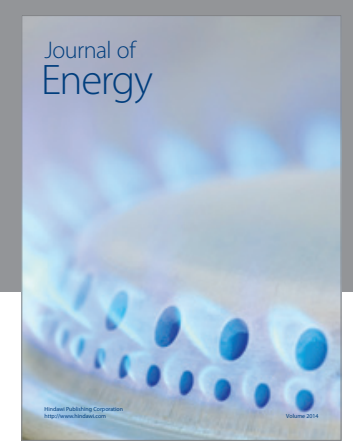

Journal of

Industrial Engineering
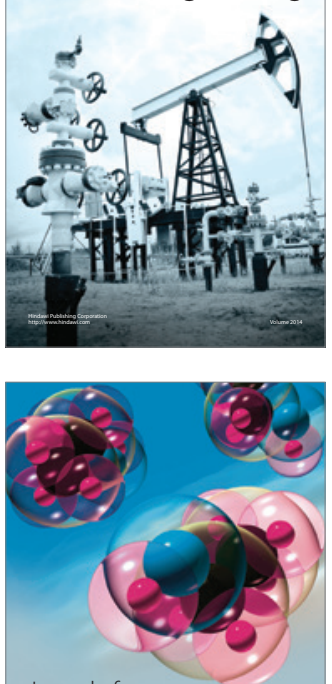

Fuels
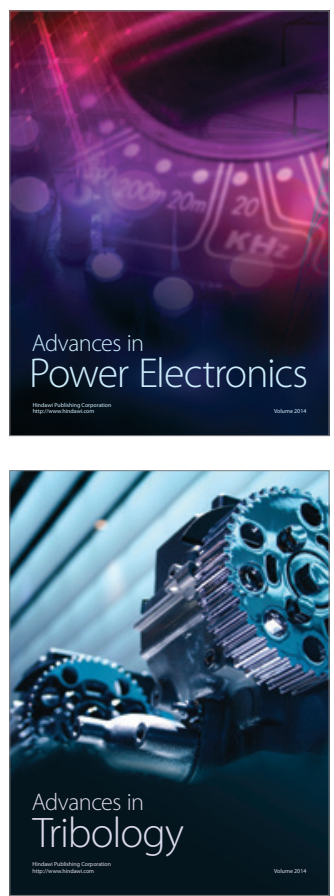

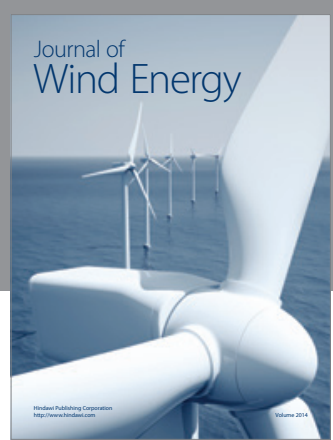

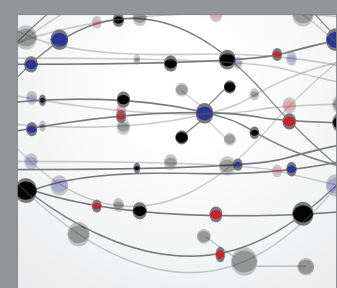

The Scientific World Journal

Submit your manuscripts at http://www.hindawi.com

Journal of

Structures
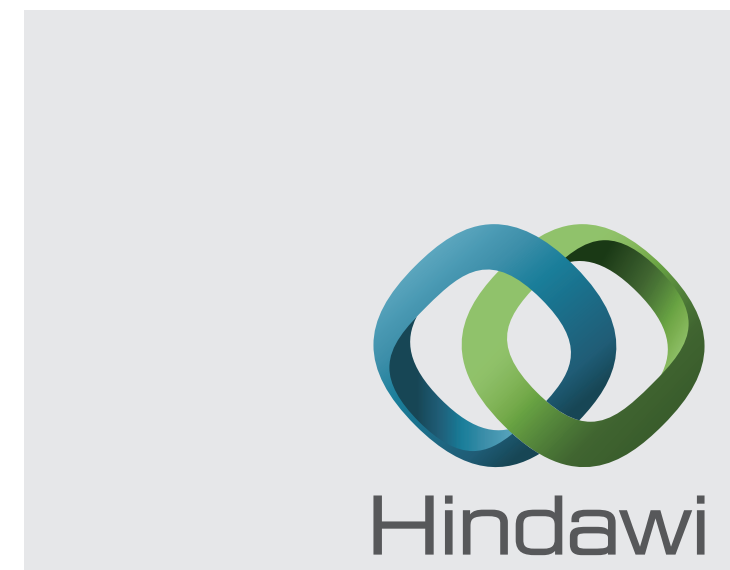

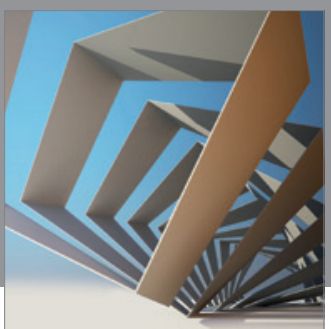

Rotating

Machinery
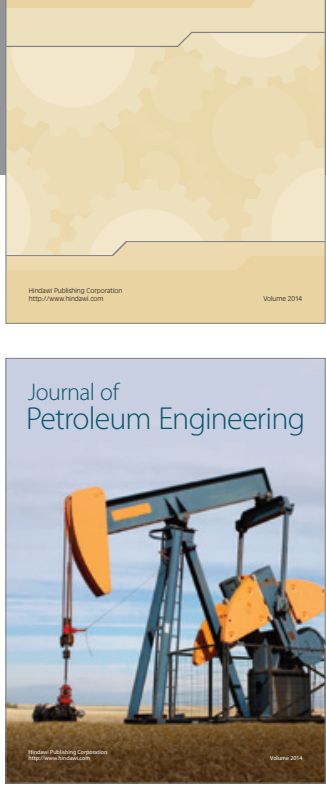

Journal of

Solar Energy
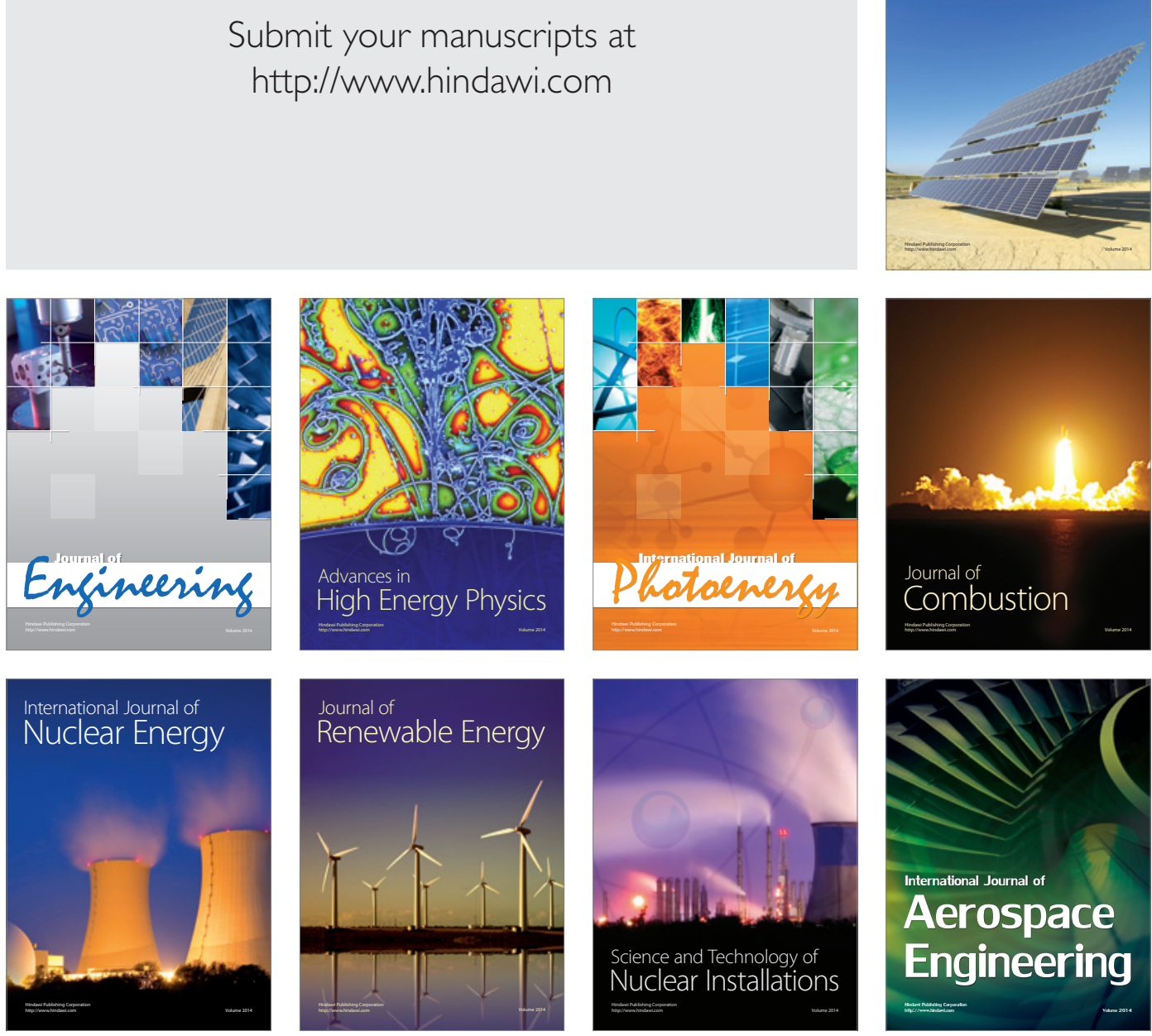